\title{
Retrocrural Lymph Node
}

National Cancer Institute

\section{Source}

National Cancer Institute. Retrocrural Lymph Node. NCI Thesaurus. Code C103439.

A lymph node located within the most inferior portion of the posterior mediastinum.

$(\mathrm{NCl})$ 